\title{
Ethnologies
}

The Flowering Thorn: International Ballad Studies. By Thomas

A. McKean, ed. (Logan, Utah: Utah State University Press, 2003.

Pp. 388, index. ISBN 0-87421-568-4)

\section{David Gregory}

Volume 26, numéro 2, 2004

Québec - Ethnologie du proche

Québec - Ethnology At Home

URI : https://id.erudit.org/iderudit/013756ar

DOI : https://doi.org/10.7202/013756ar

Aller au sommaire du numéro

\section{Éditeur(s)}

Association Canadienne d'Ethnologie et de Folklore

ISSN

1481-5974 (imprimé)

1708-0401 (numérique)

Découvrir la revue

Citer ce compte rendu

Gregory, D. (2004). Compte rendu de [The Flowering Thorn: International Ballad Studies. By Thomas A. McKean, ed. (Logan, Utah: Utah State University Press, 2003. Pp. 388, index. ISBN 0-87421-568-4)]. Ethnologies, 26(2), 315-317.

https://doi.org/10.7202/013756ar d'utilisation que vous pouvez consulter en ligne.

https://apropos.erudit.org/fr/usagers/politique-dutilisation/ 
The Flowering Thorn: International Ballad Studies. By Thomas A. McKean, ed. (Logan, Utah: Utah State University Press, 2003. Pp. 388, index. ISBN 0-87421-568-4)

This is a good example of a book that might more suitably have been published online. Essentially it is a record of the 1999 International Ballad Conference held in Aberdeen, but it has taken until now to get the papers into print. There are many good articles here, to which undoubtedly we will be directing our students, but they could have been available in a more accessible format several years ago. In the meantime, some of the authors of the original papers have taken the opportunity to expand their oral offerings into essays that would have taken more than an hour to deliver, while others have apparently left well alone. The result is something of a mishmash, and it is difficult to make valid generalisations about a volume the contents of which vary so greatly. To be sure, all the contributions have some connection with balladry, although in a few cases only barely so, but the subject matter ranges widely, touching on fifteen different cultures and eleven languages. That very breadth makes the book fascinating to dip into, yet few scholars (and certainly not this one) would have the expertise to evaluate all the articles adequately. Nor is any one reader likely to find everything in the book of great interest. Most will pick out the pieces that relate most closely to their own interests and skim the rest.

The editor, Thomas McKean, has struggled hard to impose some order on the chaos, arranging the twenty-six articles into five categories with the following titles: "Now She's Fairly Altered Her Meaning: Interpreting Narrative Song"; "Malign Forces that Can Punish and Pardon: Structure and Motif"; "Recapturing the Journey: Cruxes of Context, Version and Transmission"; "Regions, Reprints and Repertoires"; and "Purement scientifique et archéologique': The Mediating Collector". The problem is that several of these categories are vague and arbitrary. For example, the first and third categories are virtually interchangeable, and the fourth and fifth could easily be collapsed together. Moreover the second category comprises a pair of papers (Bill McCarthy's illuminating discussion of rhyme schemes in the Child canon and Simon Furey's more technical analysis of dislocation between text and tune in certain Catalan folksongs) that deal with structural issues and another pair (Larysa Vakhnina on poisoning in Ukrainian ballads and Nicolae Constantinescu on foundation sacrifice in East European song) that focus on motifs. These pairs are as different 
as chalk and cheese, and one wonders why they were combined, especially since not all the ballads in question depict "malign forces". In short, the after-the-fact organizational structure imposed on these twenty-six articles quickly breaks down upon close scrutiny, and what we are left with is the papers themselves. Not surprisingly for a publication of this type, the value of the book lies in the quality of those individual articles. And, equally unsurprisingly, the length and quality varies markedly.

By placing seven of the longer pieces in his first section, McKean has implicitly privileged them as good examples of the variety of methodologies found in ballad scholarship, an eclecticism that he champions in his introductory essay. There are some well-known names here: Luisa Del Giudice, Vic Gammon, Pauline Greenhill, Gerald Porter and Roger Renwick among them. It is useful to have print versions of good papers that one remembers from past conferences, such as Gammon's account of music as a sirenic motif in British balladry, and Greenhill's analysis of the symbolic significance of women's travel in the Newfoundland corpus. I found interesting, if somewhat inconclusive, Porter's discussion of the relative lack of "insider" occupational songs from the carpentry trade. But if I was asked to single out one paper that I would beyond question recommend as a "must read" it would be Renwick's "The Servant Problem in Child Ballads", a model of economy, clarity, insight and imagination.

On the other hand, there are a few disappointments. I found Valentina Bold's attack on a number of Scottish collectors, including Gavin Greig and Hamish Henderson, as "colonizers", flawed by a tendentious misuse of inappropriate terminology. I have great respect for Sigrid Rieuwerts' work on Francis James Child, but her quasi-defence of Child's claim that Peter Buchan rewrote his texts to make them more "vulgar" inexplicably fails to take into account David Buchan's vindication of those texts in The Ballad and the Folk. Moreover, this was an instance when a firm editorial hand was required. The name of Victorian collector/editor, Charles Mackay, is misspelled as Mackey. More importantly, Rieuwerts claims, erroneously, that when editing Scottish Traditional Versions of Ancient Ballads for the Percy Society, James Henry Dixon failed to credit Buchan with the texts; a cursory reading of Dixon's preface will put that myth to rest. Dixon was Buchan's sole 
champion in Victorian England. Moreover, Rieuwerts is also wrong when she states that Robert Bell's Ancient Poems, Ballads, and Songs was a reissue of Scottish Traditional Versions; it was rather an expanded and revised version of Dixon's other publication, Ancient Poems, Ballads, and Songs of the Peasantry of England.

Insufficient space makes it impossible to mention, let alone discuss, all the other papers in this collection, and those I single out likely reflect my own interests more than anything else. Cozette Griffin-Kremer's "May Day and Mayhem: Portraits of a Holiday in Eighteenth-century Dublin Ballads" and Sheila Douglas' "The Life and Times of Rosie Anderson" show that exploration of texts in the context of social history can be very fruitful. David Atkinson's "George Collins' in Hampshire" and Julia Bishop's "The White Fisher': An Illegitimate Child Ballad from Aberdeenshire" demonstrate that, in expert hands, a systematic examination of a single cluster of texts can be most illuminating. I learned much about French and Slovenian ballads from papers by Michèle Simonsen and Marjetka Golez Kaucic respectively, while my total ignorance of Flemish folksong was in some measure corrected by the informative articles of Isabelle Peere and Stefaan Top. For those interested in Scottish traditional music there is much to enjoy, including Lynn Wollstadt's "A Good Man Is Hard to Find: Positive Masculinity in the Ballads Sung by Scottish Women", Katherine Campbell's "Ballad Singing in New Deer", Frances Fischer's "Scotland's Nordic Ballads", and Mary Anne Alburger's examination of Simon Fraser's 1816 instrumental collection, Airs and Melodies. In short, The Flowering Thorn is a snapshot of ballad scholarship at the beginning of the twenty-first century. It is not a book to read from beginning to end but rather a potpourri in which one can find many delights and much useful information, provided that one is content to sample the contents according to one's own tastes. 